\title{
Parenting Styles and Alcohol Use in Brazilian Males
}

\author{
Elke do Pillar Pinheiro ${ }^{1}$ \\ Paula Inez Cunha Gomide ${ }^{2}$
}

\begin{abstract}
Parenting styles have been identified as some of the most important factors of risk for and protection against alcohol use among adolescents. This study aimed at comparing maternal and paternal parenting styles in groups of adult alcoholic and nonalcoholic men. Participants were 260 adult males, half of whom had been diagnosed with alcoholism whilst the others did not have a history of such disorder. The comparison between the alcoholic and control groups showed a statistically significant difference $(p<0.001)$ in relation to both paternal and maternal parenting practices. The binary logistic regression model containing paternal PSI, age, education and maternal PSI $\left(\chi^{2}=5.224 ; p=0.022 ; \mathrm{R}^{2}{ }_{\text {Nagelkerke }}=0.801\right)$ showed that paternal PSI was the main predictor of alcoholism.
\end{abstract}

Keywords: parenting style, alcoholism, men, educational status, adult

\section{Estilos Parentais e Consumo de Álcool em Homens Brasileiros}

Resumo: Estilos parentais têm sido identificados como um dos mais importantes fatores de risco e proteção para uso de álcool entre adolescentes. $\mathrm{O}$ objetivo do presente estudo foi comparar estilos parentais maternos e paternos em grupos de homens adultos alcoolistas e não alcoolistas. Participaram 260 homens, sendo metade com diagnóstico para alcoolismo e os demais sem a presença de alcoolismo. A comparação entre práticas parentais do grupo de alcoolistas com o controle mostrou diferença estatisticamente significativa $(p<0,001)$ tanto para as práticas paternas, como maternas. O modelo de regressão logística binária contendo IEP paterno, idade, escolaridade e IEP materno $\left(\chi^{2}=5,224 ; p=0,022 ; \mathrm{R}^{2}{ }_{\text {Nagelkerke }}=0,801\right)$ mostrou que o IEP paterno é o principal preditor do alcoolismo.

Palavras-chave: estilo parental, alcoolismo, homens, escolaridade, adultos

\section{Estilos Parentales y Consumo de Alcohol em Hombres Brasilienos}

Resumen: Estilos parentales han sido identificados como uno de los más importantes factores de riesgo y protección para el uso de alcohol entre los adolescentes. El objetivo del presente estudio fue comparar estilos parentales maternos y paternos en grupos de alcohólicos y controles. Participaron 260 hombres adultos, siendo la mitad con diagnóstico para alcoholismo y los demás, sin la presencia de alcoholismo. La comparación entre prácticas parentales del grupo de alcohólicos con el control presentó diferencia estadísticamente significativa $(p<0,001)$ tanto para las prácticas paternas, como maternas. El modelo de regresión logística binaria que contiene IEP paterno, edad, escolaridad y IEP materno $\left(\chi^{2}=5,224 ; p=0,022 ; \mathrm{R}^{2}{ }_{\text {Nagelkenke }}=0,801\right)$ reveló que el IEP paterno es el principal predictor del alcoholismo.

Palabras clave: estilo parental, alcoholismo, hombres, escolaridad, adulto

${ }^{I}$ Pontifícia Universidade Católica do Paraná, Curitiba-PR, Brazil

${ }^{2}$ Universidade Tuiuti do Paraná, Curitiba-PR, Brazil

Article derived from a master's thesis by the first author under supervision by the second author, defended in 2012, in the Graduate Program in Health Sciences of Pontifícia Universidade Católica do Paraná.

Correspondence address: Paula Inez Cunha Gomide. Universidade Tuiuti do Paraná. Rua Sydnei Antonio Rangel Santos, 238 - Santo Inácio, Curitiba-PR, Brazil. CEP 82.010-330. E-mail: paulainezgomide@gmail.com
Studies have shown that the various parenting styles involved in parent-child relationships act as psychosocial variables capable of exerting a great influence on the adoption of diverse health-threatening behaviors among young people, including psychoactive substance use (Calafat, García, Juan, Becoña, \& Fernández-Hermida, 2014; Martínez-Loredo et al., 2016). Lack of moral behavior (Nurco \& Lerner, 1996), negative moral emotions, such as shame and guilt 
(Luk et al., 2016), physical and psychological abuse and neglect are all predictors of alcohol use by teenagers (Martínez-Loredo et al., 2016). Parental disapproval of alcohol use and a good parent-child relationship are both associated with lower levels of drinking in later adolescence (Ryan, Jorm, \& Lubman, 2010). Epidemiological studies indicate that the onset of the use of alcohol, cigarettes and other drugs mainly occurs during adolescence, continuing into adult life (Clark, Yang, McClernon, \& Fuemmeler, 2015; Laranjeira, Pinsky, Zaleski, \& Caetano, 2007). The Health Ministry pointed out that $17.9 \%$ of Brazil's adult population consumes alcoholic beverages to excess (Ministério da Saúde, 2019). Excessive alcohol consumption is associated with poor academic performance, dangerous driving, violent behavior, loss of memory or consciousness and physical and professional shortcomings (Miller et al., 2015).

Various parental behaviors are associated with both the age at which a teenager begins drinking and subsequent drinking problems(Penjor, Thorsteinsson, Price, \&Loi,2019). Drug use by parents themselves, their permissive attitudes in the face of such use by their children and their incapacity to control their children are predisposing factors for initiating or continuing drug use (Berge, Sundell, Ojehagen, \& Hakansson, 2016; Cablova, Csemy, Belacek, \& Miovsky, 2016; Calafat et al., 2014; Luk et al., 2016; Paiva, Bastos, \& Ronzani, 2012; Valente, Cogo-Moreira, \& Sanchez, 2017). Lack of support and negligence on the part of parents can make adolescents more vulnerable to drug abuse, especially because this can increase the likelihood of their involvement with peers that use drugs (MartínezLoredo et al., 2016; Valente et al., 2017). Authoritarian, aggressive parents make it difficult for their children to communicate and reveal their problems and feelings, which can be a risk factor for alcohol use (Hartman et al., 2015). Luk et al. (2016) found that fathers that exhibit great negligence, insufficient control and little affection as well as authoritarian mothers favor the development of depressive symptoms and alcohol use in adolescents.

In contrast, democratic parenting styles can be protection factors against alcohol use (Berge et al., 2016; Clark et al., 2015), favoring the expression of feelings, arguments and, consequently, problems, and they are associated with low levels of both alcohol use and alcohol-related problems (Hartman et al., 2015). The use of well-established rules and quality communication are associated with a low level of alcohol use by teenagers (Cablova et al., 2016; Valente et al., 2017). Parental supervision serves to discourage alcohol use. Li, Simons-Morton, Brooks-Rusad, Ehsahid and Hingson (2014) found that parental control by fathers is a more effective protection factor than is parental control by mothers. Seeking to know the whereabouts of one's children, paying attention to their activities, knowing who their friends are, what they do during their free time and how they spend their money, being capable of responding to their demands and being present in a constructive manner are all considered measures that represent parents' efforts to monitor and watch over their children, that is, they are tied to parents' knowledge about their children (Gomide, 2006). Adolescents that perceive their family's rules of control, with parental monitoring and affection, exhibit lower levels of involvement with drugs (Paiva et al., 2012; Valente et al., 2017). Positive parenting practices increase selfesteem (Penjor et al., 2019) and people with high self-esteem are less likely to report problems with alcohol use or abuse (Luk et al., 2016).

Peer influence is considered a risk factor for excessive drinking in adolescents, and parenting style can have an adaptive, protective function, that is, responsible, attentive parents act as a protection factor against engaging in excessive alcohol use whereas negative family interactions favor youth risk behavior. Although parental control tends to decrease as adolescents grow older, positive monitoring during adolescence serves as a protection factor against alcohol and cigarette use in both adolescence and adult life (Piko \& Balázs, 2012). There is evidence that the manner in which mothers interact with their children strongly influences drinking behavior in adolescents, in terms of preventing or encouraging excessive alcohol use (Paiva et al., 2012).

Several theoretical models for assessing parenting practices and styles have been developed in the last five decades. Baumrind (1971) presented the first model for classifying parenting styles, consisting of three types: authoritative, authoritarian and permissive. The instrument was translated into Portuguese and adapted by Costa, Teixeira and Gomes (2000). This instrument and the Parenting Styles Inventory (PSI) (Gomide, 2006) are the two most commonly employed instruments for measuring parenting practices in Brazilian studies (Macarini, Martins, Minetto, \& Vieira, 2010; Rios, Ferreira, \& Batista, 2016). $P S I$ is the only instrument that measures moral behavior as a parenting practice. Nurco and Lerner (1996) called attention to the association between deficient paternal moral behavior and drug use by teenagers

Gomide's theoretical model (Gomide, 2006) consists of seven parenting practices, two of which are positive (positive monitoring and moral behavior) and are associated with the development of prosocial behavior; and five are negative (negligence, physical abuse, negative monitoring, inconsistent punishment and relaxed discipline) and are related to the development of antisocial behavior, including alcoholism. The author defines parenting style as a series of parenting practices used by parents to educate and socialize their children and control their behaviors, and parenting practices are the specific strategies parents employ in different contexts. This means that the parenting style is the result of the confluence of forces from parenting practices, that is, in a positive parenting style, positive parenting practices prevail over negative ones whereas, if the parenting style is negative, negative practices override positive practices. Positive monitoring encompasses parental monitoring or supervision and parental availability or accessibility; moral behavior involves affectionate childrearing practices that transmit values (politeness, fairness, honesty/dishonesty, generosity); negligence amounts to a lack of affection, 
of childrearing care and of health; negative monitoring refers to excessive, hostile supervision; inconsistent punishment involves conflicting disciplinary practices that depend on the parent's mood; relaxed discipline encompasses the lack or precariousness of parental rules; and physical punishment is the use of corporal discipline as a childrearing method.

Three Brazilian surveys have related parenting styles to teenage alcoholism (Paiva et al., 2012; Valente et al., 2017; Zuquetto et al., 2019), employing self-report instruments to report parenting practices and alcohol use. The participants reported the number of doses of alcohol they normally ingested on a single occasion, which served as the criterion for forming groups of frequent, moderate or occasional drinkers. International surveys of university students have employed self-reports of parenting practices in a retrospective manner (Hartman et al., 2015; Luk et al., 2016; Penjor et al., 2019). There are no records of Brazilian or international studies that have performed a retrospective assessment of parenting practices in relation to adult males diagnosed with alcoholism. Hence, the objective of the present study was to compare the maternal and paternal parenting styles of individuals who had been diagnosed with alcoholism to those of another group who did not have a history of alcoholism.

\section{Method}

\section{Participants}

The present study counted on the participation of 260 male volunteers, all of whom were Caucasians over the age of 21. They were divided into two groups: the alcoholic group consisted of 130 volunteers who were inpatients in a men's alcohol treatment unit at a psychiatric hospital and had been diagnosed with alcoholism according to ICD-10 (Organização Mundial da Saúde, 1993) by one of the institution's psychiatrists. The control group consisted of 130 males with no history of alcoholism who were selected by exclusion subsequently to responding to two instruments: the CAGE questionnaire (Mayfield, McLeod, \& Hall, 1974) and a questionnaire adapted from ICD-10 (Organização Mundial da Saúde, 1993).

Most of the participants in the control group were undergraduates $(56.15 \%)$ or had a higher level of education $(20 \%)$, with only $23.85 \%$ of the sample showing a lower level of academic skills (complete or incomplete high-school education $=15.38 \%$; complete or incomplete elementaryschool education $=8.46 \%$ ). In contrast, only a few of the participants in the alcoholic group were undergraduates $(4.6 \%)$ or showed higher education $(10 \%)$; the great majority had complete or incomplete high-school education (37.8\%) or complete or incomplete elementary-school education (47.6\%). Alcoholism diagnosis for the 260 participants was performed according to the ICD-10 (Organização Mundial da Saúde, 1993) and CAGE (Mayfield et al., 1974) questionnaires.

\section{Instruments}

Three instruments were employed for data collection: the CAGE questionnaire (Mayfield et al., 1974), a questionnaire adapted from ICD-10 (Organização Mundial da Saúde, 1993) by the present researchers and the Parenting Styles Inventory (PSI) (Gomide, 2006).

Developed by Mayfield et al. (1974), the CAGE questionnaire is a screening method for detecting alcoholism, consisting of four questions: Have you ever tried to cut down on your drinking? Have people annoyed you about your drinking? Have you ever felt guilty about your drinking? Have you ever had a drink first thing in the morning to steady your nerves or to get rid of a hangover? If at least one answer to these questions is affirmative, then alcohol-related problems may be suspected of; two or more affirmative answers indicate alcohol-related problems.

The questionnaire adapted from ICD-10 (Organização Mundial da Saúde, 1993) by the present researchers. This questionnaire consists of nine questions based on ICD-10's nine criteria for alcoholism: (1) Have you ever felt a strong desire or compulsion to consume alcoholic beverages?; (2) Have you ever felt incapable of stopping drinking after you began?; (3) Have you ever felt the need to drink again in order to relieve or alleviate symptoms of alcohol abstinence?; (4) Do you occasionally feel that you need to drink more in order to attain the sense of well-being that you usually feel when you drink?; (5) Have you ever abandoned your obligations, family or work for two or more days?; (6) Have you ever experienced delirium tremens, felt the shakes or heard voices or seen things that did not exist after drinking heavily?; (7) Have you ever been hospitalized because of drinking?; (8) Have you ever been arrested or fined for drunk driving?; (9) In the previous two generations (your father's or your mother's), were there any alcoholics? Participants that responded affirmatively to at least five of these questions were characterized as alcoholics and were excluded from the study.

$P S I$ consists of 42 questions that assess the parenting practices employed by parents in the education of their children. Seven parenting practices are assessed: two positive practices (A) positive monitoring (He/she asks me how my school day was and listens attentively) and (B) moral behavior (When I damage something that belongs to others, he/she instructs me to tell them what I did and apologize) and five negative practices (C) negligence (I feel that he/she pays no attention to me), (D) inconsistent punishment (When happy, he/she does not care about the wrongful things I do), (E) relaxed discipline (He/she threatens to beat me, but later nothing happens), (F) negative monitoring (When I go out, he/she calls me a lot) and (G) physical abuse (He/she beats me using belts or other objects). Six questions correspond to each variable. Respondents answer the questions according to a 3-point Likert scale (never, sometimes and always). Calculation of the parenting style index is performed by 
subtracting the sum of negative variables $(\mathrm{C}+\mathrm{D}+\mathrm{E}+\mathrm{F}+\mathrm{G})$ from the sum of positive variables $(\mathrm{A}+\mathrm{B})$; i.e., $P S I=(\mathrm{A}+\mathrm{B})$ $(\mathrm{C}+\mathrm{D}+\mathrm{E}+\mathrm{F}+\mathrm{G})$.

PSI classifies the results (for both parenting practices and parenting style) according to four categories: (1) excellent, (2) good, (3) regular and (4) risky. Based on the theoretical model of the test (Gomide, 2006), this classification indicates the adequacy of the parenting practices and parenting style and the potential implications of employing negative practices in childrearing. Results classified as "excellent" or "good" ( 1 and 2) indicate that most of the parenting practices focus on strengthening prosocial skills, with emphasis on monitoring the children and teaching them moral conduct whereas results classified as "regular" or "risky" (3 and 4) indicate prevalence of negative parenting practices that are associated with the development of antisocial behaviors. Cronbach's alpha for maternal and paternal PSI showed reasonable internal consistency coefficients, 0.75 , and 0.79 , respectively.

\section{Procedures}

Data collection. The researcher explained the objectives of the study to the volunteers, and those who accepted signed an informed consent form. The participants were instructed to respond in terms of the parenting practices employed by their parents when the participants were adolescents. The group of alcoholic participants answered the maternal and paternal PSIS individually in rooms designated by the hospital, taking 40 minutes on average. The controlgroup participants answered the CAGE questionnaire first, and those who answered at least two of the four questions affirmatively were excluded. Subsequently, the remaining participants answered the questionnaire adapted from ICD-10, and those who answered at least five of the nine questions affirmatively (positive screening for alcoholism) were excluded. Subsequently to the two procedures above, the control-group participants signed an informed consent form and then responded to the maternal and paternal versions of the Parenting Styles Inventory. Data collection for the control group lasted an average of 30 minutes.

Data analysis. The data were analyzed using SPSS (Statistical Package for Social Sciences) software, version 22.0. The medians and statistical significance for the Mann-Whitney $U$ test for independent samples in relation to maternal and paternal parenting practices and academic achievement levels were calculated for the alcoholic- and control- group participants. In order to assess the relation between PSIs (maternal and paternal), considering age and academic skills as covariables, a logistic regression model and the Wald test were used, taking into consideration $p$ values $<0.05$.

\section{Ethical Considerations}

This project was approved by the Brazilian National Research Ethics Council (registration number 13447) and by the Research Ethics Committee of Pontifícia Universidade
Católica do Paraná (registration number 102). The ethics committee of the hospital in which the alcoholic patients were being treated also evaluated and approved the project (registration number 027SM 003-07-05 (CAAE $\mathrm{n}^{\circ}$ 0158.0.084.000-06). Participants who agreed to take part in the study signed an informed consent form, which was drawn up in accordance with Resolution 466/2012 (CNS).

\section{Results}

The mean age of participants in the alcoholic group was $47.2(S D=9.1, \min =18, \max =75)$ and that of participants in the control group was $36.1(S D=10.8, \min =20, \max =73)$. The history of alcoholic antecedents for the alcoholic group showed that $91.5 \%$ of the surveyed alcoholics had at least one alcoholic antecedent. The highest percentage observed was among fathers $(63.1 \%)$, followed by brothers $(40.7 \%)$, uncles $(33.1 \%)$, grandfathers $(18.5 \%)$, mothers $(5.4 \%)$ and grandmothers $(3.1 \%)$. In contrast, in the non-alcoholic (control) group, due to the conditional type of selection (only those with no ancestors with a history of alcoholism were included the group), there was no incidence whatsoever of a history of alcoholism. A Kolmogorov-Smirnov normality test of the sample rejected Ho for the maternal PSI (K-S = $0.137 ; p<0.001)$ and paternal PSI $(\mathrm{K}-\mathrm{S}=0.096 ; p<0.001)$. The null hypothesis assumes that the maternal and paternal parenting practices are normally distributed in the sample.

The participants answered the paternal and maternal versions of $P S I$ (Table 1). A comparison between the parenting practices of the experimental and control groups showed a statistically significant difference $(p<0.001)$ for both paternal and maternal childrearing practices, with indicators of a risky parenting style for the alcoholics for both fathers (-13) and mothers (-9.5) (Table 1). Negligence, relaxed discipline and physical abuse rates were exceptionally high in the alcoholic group, while lack of both positive monitoring and moral conduct characterized the parenting practices of the alcoholics' parents.

The participants' academic skills level was statistically different between the two groups $(p<0.001)$. In the alcoholic group, $83.9 \%$ of the participants had complete or incomplete elementary- or high-school education whereas, in the control, group most of the participants $(77 \%)$ had complete or incomplete university education.

Binary logistic regression was performed in order to check whether maternal PSI, paternal PSI, academic skills and age were predictors of alcoholism (Table 2). The data met the necessary criteria for this analysis, that is, the absence of both multicollinearity and outliers. The model containing the paternal $P S I$ variable alone was significant $\left(\chi^{2}=170.858 ; p<\right.$ $\left.0.001 ; \mathrm{R}_{\text {Nagelkerke }}^{2}=0.642\right)$. As the other variables were added, the model continued to be significant and better explained alcoholism, as was the case in the model containing paternal $P S I$ and age variables $\left(\chi^{2}=50.923 ; p<0.001 ; \mathrm{R}_{\text {Nagelkerke }}^{2}\right.$ $=0.765)$, the model with paternal PSI, age and academic skills variables $\left(\chi^{2}=11.745 ; p<0.001 ; \mathrm{R}^{2}{ }_{\text {Nagelkerke }}=0.790\right)$ and the 
Pinheiro, E. P., \& Gomide, P. I. C. (2020). Parenting Styles and Alcohol.

model with paternal PSI, age, academic skills and maternal $P S I$ variables $\left(\chi^{2}=5.224 ; p=0.022 ; \mathrm{R}^{2}{ }_{\text {Nagelkerke }}=0.801\right)$. The correlation between age and alcoholism was negative (i.e., older ages were related to the presence of alcoholism). It was thus perceived that paternal PSI was the main predictor of alcoholism. Such predictive capacity increased when it was considered together with age and academic skills. Adding maternal PSI to the regression model continued to maintain the significance of the model, yet it was observed that such variable added little to its predictive capacity.

Table 1

Medians, classification of results and statistical significance for the Mann-Whitney U test in relation to Maternal and Paternal Parenting Practices of the Alcoholic and Control Groups

\begin{tabular}{|c|c|c|c|c|c|c|}
\hline \multirow[t]{2}{*}{ Parenting Practices } & \multicolumn{3}{|c|}{ Maternal } & \multicolumn{3}{|c|}{ Paternal } \\
\hline & Alcoholics & Control & $p$ & Alcoholics & Control & $p$ \\
\hline PM & $8(4)$ & $9(3)$ & $p<0.001$ & $6(4)$ & $7(4)$ & $p=0.01$ \\
\hline $\mathrm{MC}$ & $7(4)$ & $9(3)$ & $p<0.001$ & $7(3)$ & $8(3)$ & $p=0.001$ \\
\hline IP & $5(4)$ & $2(2)$ & $p<0.001$ & $5(4)$ & $3(2)$ & $p<0.001$ \\
\hline NE & $4(4)$ & $2(2)$ & $p<0.001$ & $6(4)$ & $3(3)$ & $p<0.001$ \\
\hline $\mathrm{RD}$ & $5(4)$ & $3(3)$ & $p<0.001$ & $4(4)$ & $2(2)$ & $p<0.001$ \\
\hline NM & $7(4)$ & $6(3)$ & $p=0,001$ & $6(3)$ & $4(2)$ & $p=0.001$ \\
\hline PA & $3(4)$ & $1(3)$ & $p<0.001$ & $5(4)$ & $2(2)$ & $p<0.001$ \\
\hline PSI & $-9.5(4)$ & $2(3)$ & $p<0.001$ & $-13(4)$ & $2(3)$ & $p<0.001$ \\
\hline
\end{tabular}

Note. $\mathrm{PM}=$ Positive Monitoring; $\mathrm{MC}=$ Moral Conduct; IP = Inconsistent Punishment; NE = Negligence; RD = Relaxed Discipline; $\mathrm{NM}=$ Negative Monitoring; PA = Physical Abuse. Classification of results: (1) excellent, (2) good, (3) regular and (4) risky.

Table 2

Goodness-of-fit indices and variables present in the binary logistic regression models for the presence of alcoholism

\begin{tabular}{|c|c|c|c|}
\hline Model 1 & \multicolumn{2}{|c|}{ Log Likelihood } & Nagelkerke $\mathrm{R}^{2}$ \\
\hline & \multicolumn{2}{|c|}{189.579} & 0.642 \\
\hline Variables in the final model & $\mathrm{B}$ & Wald & $\operatorname{Exp}(B)$ \\
\hline Paternal PSI & 0.288 & 61.628 & 1.334 \\
\hline Constant & 0.895 & 22.421 & 2.449 \\
\hline \multirow[t]{2}{*}{ Model 2} & \multicolumn{2}{|c|}{ Log Likelihood } & Nagelkerke $\mathrm{R}^{2}$ \\
\hline & \multicolumn{2}{|c|}{138.656} & 0.765 \\
\hline Variables in the final model & $\mathrm{B}$ & Wald & $\operatorname{Exp}(B)$ \\
\hline Age & -0.127 & 34.903 & 0.881 \\
\hline Paternal PSI & 0.249 & 42.853 & 1.282 \\
\hline Constant & 5.926 & 39.843 & 374.552 \\
\hline \multirow[t]{2}{*}{ Model 3} & \multicolumn{2}{|c|}{ Log Likelihood } & Nagelkerke $\mathrm{R}^{2}$ \\
\hline & \multicolumn{2}{|c|}{126.911} & 0.790 \\
\hline Variables in the final model & $\mathrm{B}$ & Wald & $\operatorname{Exp}(B)$ \\
\hline Academic skills & 0.530 & 10.952 & 1.699 \\
\hline Age & -0.129 & 33.248 & 0.879 \\
\hline Paternal PSI & 0.219 & 33.468 & 1.245 \\
\hline Constant & 3.693 & 11.136 & 40.174 \\
\hline \multirow[t]{2}{*}{ Model 4} & \multicolumn{2}{|c|}{ Log Likelihood } & Nagelkerke $\mathrm{R}^{2}$ \\
\hline & \multicolumn{2}{|c|}{121.687} & 0.801 \\
\hline Variables in the final model & B & Wald & $\operatorname{Exp}(B)$ \\
\hline Academic skills & 0.476 & 8.720 & 1.610 \\
\hline Age & -0.126 & 31.884 & 0.881 \\
\hline Maternal PSI & 0.061 & 5.002 & 1.063 \\
\hline Paternal PSI & 0.201 & 27.040 & 1.222 \\
\hline Constant & 3.918 & 12.151 & 50.276 \\
\hline
\end{tabular}




\section{Discussion}

Previous studies had indicated a correlation between parenting practices and alcoholism. Negative parenting practices, such as lack of monitoring or supervision (Berge et al., 2016; Cablova et al., 2016; Piko \& Balázs, 2012), negligence (Valente et al., 2017), physical abuse (Hartman et al., 2015) and lack of both rules and parental control (Paiva et al., 2012; Penjor et al., 2019), are associated with a drinking problem in adolescents and university students. These negative parenting practices are risk factors for alcohol use.

Our results showed significant parenting-style differences between the alcoholics and non-alcoholics. According to Gomide's model (2006), a positive parenting style is evidenced when positive parenting practices (positive monitoring and moral behavior) prevail over negative practices (inconsistent punishment, negligence, relaxed discipline, negative monitoring and physical abuse); and a parenting style is negative when negative practices override positive ones. According to the alcoholic participants' perceptions, their fathers and mothers insufficiently and stressfully supervised their activities, established rules in an irregular manner, inconsistently punished them (based on their moods), employed physical punishment to control their behaviors and refrained from teaching them moral values during adolescence. Our results are in line with international studies, indicating that negative parenting practices not only increase alcohol use in adolescence, but also favor substance abuse in adult life (Cablova et al., 2016; Calafat et al., 2014; Clark et al., 2015; Valente et al., 2017).

In contrast, positive parenting practices were more frequently observed among non-alcoholics, indicating their potential protective function against alcohol use (Berge et al., 2016; Clark et al., 2015; Luk et al., 2016). The affection parents give their children, the interest they show in them, the amount of time they spend with them and the firmness they display with respect to disciplinary measures all discourage alcohol abuse (Paiva et al., 2012; Ryan et al., 2010) and are associated with good academic performance (Toni \& Hecaveí, 2014).

The low educational level observed in the alcoholic group is considered a risk factor for psychological problems (Abreu, Jomar, Souza, \& Guimarães, 2012). Compared to students who did not binge drink, those who started using alcohol and marijuana during adolescence ditched more classes, handed in incomplete schoolwork, got involved in fights, drove under the influence of alcohol and accepted rides from drivers that had been drinking (Bedendo et al., 2017; Meda et al., 2017; Paiva et al., 2012). Other antisocial behaviors, such as violations of the law, can gain strength when a student skips school and joins deviant groups (Toni \& Hecaveí, 2014).

Some studies suggest that maternal and paternal parenting practices differently influence alcohol use by teenagers. Paiva et al. (2012) found that the democratic parenting style of mothers reduced teenagers' involvement with alcohol whereas that of fathers appeared to be unrelated. Researchers have discovered that authoritarian behavior on the part of mothers, and not fathers, is associated with depression and alcohol abuse (Luk et al., 2016) and nondisclosure of problems (Hartman et al., 2015) in teenage drinkers. Nurco and Lerner (1996) associated lower levels of adolescent vulnerability to drug use with the following factors: strong attachment to the paternal figure, acceptance of beliefs concerning good conduct, and specific paternal disapproval of certain behaviors. Li et al. (2014) found that paternal control is more effective in terms of discouraging alcohol use than maternal control is.

The binary logistic regression model combining maternal PSI, paternal PSI, academic skills and age showed that paternal $P S I$ is the best predictor of alcoholism in a male sample. Maternal PSI added little to the predictive value of the model. The differences found by various authors are probably due to the theoretical constructs of the instruments used to measure parenting practices. The Gomide model (2006) favors equilibrium between parenting practices, which indicate whether the parenting style is positive or negative. The logistic regression in this study showed that paternal parenting practices, as a whole, are what most influences the onset of alcoholism in men, without highlighting any particular parenting practice. It remains necessary to check whether the model equally applies to a female sample.

Furthermore, future studies need to select alcoholicgroup and control-group participants of the same age group and educational level, given that the control-group participants in the present study were younger and more highly educated than were those in the alcoholic group. So far, studies on parenting practices have employed selfreport instruments for data collection, which could raise doubts as to the reliability of such information. Longitudinal studies could reduce potential inaccuracies in the information by making it possible to collect data at various points in the lives of the participants and crosscheck them with empirical data, such as professional stability and hospitalization for alcoholism treatment.

Consistent with the findings from other studies (both foreign and domestic), the results in the present study indicate that parenting styles exert a significant influence on the development of alcoholism (Berge et al., 2016; Cablova et al., 2016; Calafat et al., 2014; Luk et al., 2016; Martínez-Loredo et al., 2016; Paiva et al., 2012; Piko \& Balázs, 2012; Valente et al., 2017) and that positive parenting practices discourage alcohol use by teenagers. Also, the results especially call attention to the exceptional influence from paternal parenting practices as a predictor of alcoholism (Li et al., 2014; Nurco \& Lerner, 1996).

Programs aimed at enlightening and training mothers and fathers as to the importance of the coherent use of disciplinary rules, of the supervision and monitoring of their children's activities, of quality communication and of teaching moral values can be a promising path toward reducing alcohol use among teenagers. Such programs should especially sensitize fathers through research results that indicate the possibility that their parenting care can prevent or discourage alcohol abuse by their children. 


\section{References}

Abreu, A. M. M., Jomar, R. T., Souza, M. H. N., \& Guimarães, R. M. (2012). Harmful consumption of alcoholic beverages among users of a Family Health Unit. Acta Paulista de Enfermagem, 25(2), 291-295. doi:10.1590/S0103-21002012000200021

Baumrind, D. (1971). Current patterns of parental authority. Developmental Psychology, 4(1, Pt. 2), 1-103. doi: $10.1037 / \mathrm{h} 0030372$

Bedendo, A., Andrade, A. L. M., Opaleye, E. S., \& Noto, A. R. (2017). Binge drinking: A pattern associated with a risk of problems of alcohol use among university students. Revista Latino-Americana de Enfermagem, 25, e2925. doi:10.1590/1518-8345.1891.2925

Berge, J., Sundell, K., Ojehagen, A., \& Hakansson, A. (2016). Role of parenting styles in adolescent substance use: Results from a Swedish longitudinal cohort study. BMJ Open, 6, e008979. doi:10.1136/bmjopen-2015-008979

Cablova, L., Csemy, L., Belacek, J., \& Miovsky, M. (2016). Parenting styles and typology of drinking among children and adolescents. Journal of Substance Use, 21(4), 381389. doi:10.3109/14659891.2015.1040087

Calafat, A., García, F., Juan, M., Becoña, E., \& FernándezHermida, J. R. (2014). Which parenting style is more protective against adolescent substance use? Evidence within theEuropeancontext.DrugandAlcoholDependence, 138, 185-192. doi:10.1016/j.drugalcdep.2014.02.705

Clark, T. T., Yang, C., McClernon, F. J., \& Fuemmeler, B. F. (2015). Racial differences in parenting style typologies and heavy episodic drinking trajectories. Health Psychology, 34(7), 697-708. doi:10.1037/hea0000150

Costa, F. T., Teixeira, M. A. P., \& Gomes, W. B. (2000). Responsividade e exigências: Duas escalas para avaliar estilos parentais (Responsiveness and requirements: Two scales to evaluate parental styles). Psicologia: Reflexão e Crítica, 13(3), 465-473. doi:10.1590/ S0102-79722000000300014

Gomide, P. I. C. (2006). Inventário de Estilos Parentais (IEP): Modelo teórico, manual de aplicação, apuração $e$ interpretação (Parenting Styles Inventories (PSI): A theoretical model, application manual, mensuration and interpretation). Petrópolis, RJ: Vozes.

Hartman, J. D., Patock-Peckham, J. A., Corbin, W. R., Gates, J. R., Leeman, R. F., Luk, J. W., \& King, K. M. (2015). Direct and indirect links between parenting styles, selfconcealment (secrets), impaired control over drinking and alcohol-related outcomes. Addictive Behaviors, 40, 102-108. doi:10.1016/j.addbeh.2014.08.009
Laranjeira, R., Pinsky, I., Zaleski, M., \& Caetano, R. (2007). I levantamento nacional sobre os padrões de consumo de álcool na população brasileira (I national survey of the alcohol use patterns of the Brazilian population). Brasília, DF: Secretaria Nacional Antidrogas. Retrieved from https:/bvsms.saude.gov.br/bvs/publicacoes/ relatorio_padroes_consumo_alcool.pdf

Li, K., Simons-Morton, B. G., Brooks-Russell, A., Ehsani, J., \& Hingson, R. (2014). Drinking and parenting practices as predictors of impaired driving behaviors among U.S. adolescents. Journal of Studies on Alcohol and Drugs, 75(1), 5-15. doi:10.15288/jsad.2014.75.5

Luk, J. W., Patock-Peckham, J. A., Medina, M., Terrell, N., Belton, D., \& King, K. M. (2016). Perpetration and victimization as externalizing and internalizing pathways: A retrospective study linking parenting styles and self-esteem to depression, alcohol use, and alcoholrelated problems. Substance Use \& Misuse, 51(1), 113-125. doi:10.3109/10826084.2015.1090453

Macarini, S. M., Martins, G. D. F., Minetto, M. F. J., \& Vieira, M. L. (2010). Práticas parentais: Uma revisão da literatura brasileira [Parental practices: A review of the Brazilian literature]. Arquivos Brasileiros de Psicologia, 62(1), 119-134. Retrieved from http://pepsic.bvsalud.org/scielo. php?script=sci_arttext\&pid=S1809-52672010000100013

Martínez-Loredo, V., Fernández-Artamendi, S., Weidberg, S., Pericot-Valverde, I., López-Núñez, C., Fernández-Hermida, J. R., \& Secades-Villa, R. (2016). Parenting styles and alcohol use among adolescents: A longitudinal study. European Journal of Investigation in Health, Psychology and Education, 6(1), 27-36. doi:10.1989/ejihpe.v6i1.146

Mayfield, D., McLeod, G., \& Hall, P. (1974). The CAGE questionnaire: Validation of new alcoholism screening instrument. American Journal Psychiatry, 131(10), 1121-1123. doi:10.1176/ajp131.10.1121

Meda, S. A., Gueorguieva, R. V., Pittman, B., Rosen, R. R., Aslanzadeh, F., Tennen, H., ... Pearlson, G. D. (2017). Longitudinal influence of alcohol and marijuana use on academic performance in college students. PLoS One, 12(3), e0172213. doi:10.1371/journal. pone.0172213

Miller, P. G., Butler, E., Richardson, B., Staiger, P. K., Youssef, G. J., Macdonald, J. A., ... Olsson, C. A. (2015). Relationships between problematic alcohol consumption and delinquent behaviour from adolescence to young adulthood. Drug and Alcohol Review, 35(3), 317-325. doi:10.1111/dar.12345 
Ministério da Saúde. Secretaria de Vigilância em Saúde. Departamento de Análise em Saúde e Vigilância de Doenças não Transmissíveis. (2019). Vigitel Brasil 2018: Vigilância de fatores de risco e proteção para doenças crônicas por inquérito telefônico [Vigitel Brazil 2018: Surveillance of risk and protective factors for chronic diseases by telephone survey]. Brasília, DF: Autor. Retrieved from https://portalarquivos2.saude.gov.br/ images/pdf/2019/julho/25/vigitel-brasil-2018.pdf

Nurco, D. N., \& Lerner, M. (1996). Vulnerability to narcotic addiction: Family structure and functioning. Journal of Drug Issues, 26(4), 1007-1025. doi:10.1177/002204269602600415

Organização Mundial da Saúde. (1993). Classificação de transtornos mentais e de comportamento da CID-10: Descrições clínicas e diretrizes diagnósticas [The ICD10 - Classification of mental and behavioral disorders: Clinical and descriptions and diagnostic guidelines] (D. Caetano, Trans.). Porto Alegre, RS: Artmed.

Paiva, F. S., Bastos, R. R., \& Ronzani, T. M. (2012). Parenting styles and alcohol consumption among Brazilian adolescents. Journal of Health Psychology, 17(7), 1011-1021. doi:10.1177/1359105311428535

Penjor, S., Thorsteinsson, E. B., Price, I., \& Loi, N. M. (2019). Parenting style, distress, and problematic alcohol use in Bhutan. Cogent Psychology, 6(1), 1-10. doi:10.1080/23311908.2019.1579503

Piko, B. F., \& Balázs, M. A. (2012). Authoritative parenting style and adolescent smoking and drinking. Addictive Behaviors, 37(3), 353-356. doi:10.1016/j.addbeth.2011.11.022

Rios, J. B. S., Ferreira, D. F., \& Batista, E. C. (2016). Práticas educativas e estilos parentais: Uma revisão bibliográfica da literatura brasileira [Educational practices and parental styles: A literature review of Brazilian literature]. Revista UNIABEU, 9(21), 17-31. Retrieved from https://revista. uniabeu.edu.br/index.php/RU/article/view/2268/pdf_305

Ryan, S. M., Jorm, A. F., \& Lubman, D. I. (2010). Parenting factors associated with reduced adolescent alcohol use: A systematic review of longitudinal studies. Australian \& New Zealand Journal of Psychiatry, 44(9), 774-783. doi:10.1080/00048674.2010.501759

Toni, C. G. S., \& Hecaveí, V. A. (2014). Relações entre práticas educativas parentais e rendimento acadêmico em crianças [Relationship between parental practices and school performance in children]. Psico-USP, 19(3), 511521. doi:10.1519/1413-82712014019003013

Valente, J. Y., Cogo-Moreira, H., \& Sanchez, Z. M. (2017). Gradient of association between parenting styles and patterns of drug use in adolescence: A latent class analysis. Drug and Alcohol Dependence, 180, 272-278. doi:10.1016/j.drugalcdep.2017.08.015
Zuquetto, C. R., Opaleye, E. S., Feijó, M. R., Amato, T. C., Ferri, C. P., \& Noto, A. R. (2019). Contributions of parenting styles and parental drunkenness to adolescent drinking. Brazilian Journal of Psychiatry, 41(6), 511-517. doi:10.1590/1516-4446-2018-0041

Elke do Pillar Pinheiro is a psychologist at the Spiritist Hospital of Psychiatry Bom Retiro, Curitiba-PR, Brazil.

Paula Inez Cunha Gomide is a professor at the Tuiuti University of Paraná, Curitiba-PR, Brazil.

Authors' Contribution:

All authors have made substantial contributions to the conception and design of this study, to data analysis and interpretation, to manuscript revision and approval of the final version. All the authors assume public responsibility for the manuscript content.

Received: Aug. 22, 2019

1st Revision: Nov. 05, 2019

Approved: Feb. 06, 2020

How to cite this article:

Pinheiro, E. P., \& Gomide, P. I. C. (2020). Parenting styles and alcohol use in Brazilian males. Paidéia (Ribeirão Preto), 30, e3033.doi:https://doi.org/10.1590/1982-4327e3033 